\title{
11
}

\section{Working with Networks on the University Campus}

\author{
Verónica Marín Díaz \\ vmarín@uco.es \\ Orcid: 0000-0001-9836-2584 \\ Universidad de Córdoba \\ Juan Manuel Muñoz González \\ juan.manuel@uco.es \\ Orcid: 0000-0001-9332-0465 \\ Universidad de Córdoba
}

M. a Dolores Hidalgo Ariza

lola.hidalgo@uco.es

Orcid: 0000-0002-8500-1621

Universidad de Córdoba

\begin{abstract}
The universal education is today a reality. Trough the e-learning system we can access to diverse educational system for all the educational level. In this case the technical revolutions have suppose that the higher centre changes their point of view and think how arrived at all the student or possibly pupils. In this case the social networks have became in the best too to get the principal objective of the universities, the communicate with all the student and teachers. In this chapter we presented different social nets for all the world and how the universities made themselves known to the world.
\end{abstract}

Keywords: social networks, University, teacher, student, innovation

\subsection{Introduction}

The era of information and communication is currently experiencing a time of constant revolution (Bidarrian, Bidarrian, \& Davoud, 2011), although in past times this circumstance was the result of diverse and profound changes in all areas in which society was developed, today it comes hand in hand with the continuous changes that take place in information and communi- 
cation technologies (ICT).The new social, political, educational, and economic organization, which is presented, revolves around the absolute power of the demonstrations (hardware and software) that ICTs show. This new panorama demands, in consequence, on the one hand the remodeling or reformulation of the already existing professional profiles and on the other the design of new ones, circumstance that to a large extent affects the educational systems under many and various aspects of its detailed expression.

According to Uzunboylu, Bicen, \& Cavus (2011) there are three elements that have accelerated this new society and that therefore affect the educational systems, both in their organization and in their classroom dynamics - concerning the teacher-, namely:

- the rapid growth of scientific knowledge;

- the growth of the popularity of digital culture;

- learning can be done anytime, anywhere.

The first one involves the development of the necessary skills for the progress of information. While the second element implies a new vision of the digital dimension, which entails redefining the roles that consumers of these resources have. Finally, the possibility that is given to learning not only throughout life, but that this can be done 24 hours a day, 7 days a week (Prensky, 2008). As we see everything revolves around the conception of information, how it is recovered, reused, and redefined, in addition to the new conceptions that we assign to the protagonists of the teaching-learning processes, in the case of education, and a variable that every day is assuming more force: the so-called digital competence.

With respect to the way of working with information, the appearance of new tools that try to bring it more available and open new fields of knowledge, implying that it is understood as something flexible, fluid and variable. Hence the conception that we mentioned before the 3Rs (recover, redefine and reuse) link with the idea of 24/7 and the need to know how to combine both concepts (digital competence).

The incorporation of ICT in classrooms in general, and particularly in universities, will imply, on the one hand, a modification of traditional teaching models-transmissive, student-centered and 
collaborative (Cebrián, 2003) -and on the other, the design of a new teaching format in which the main feature will be accessing a greater number of primary information sources.

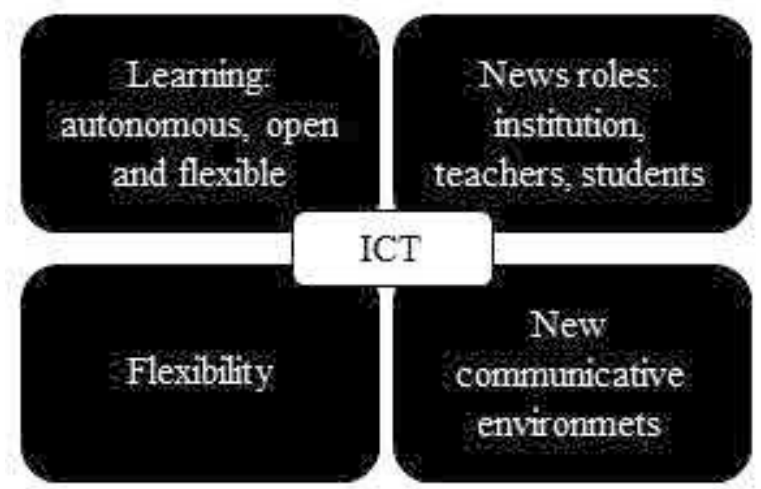

Figure 1. Incorporation of ICT to education. Source: Meneses (2006)

Along with this we also find positive aspects of this methodological approach as they are, among others, greater personal and professional growth of individuals, greater knowledge generation and theories, as well as promoting collaborative and cooperative learning among students and teachers, autonomous learning processes (Muñoz, 2004; Bidarrian, Bidarrian, \& Davoud, 2011; Álvarez, 2012). But not all are beatitudes, we also find the lack of time to be up to date on the technological developments that are generated. We believe that it is necessary to overcome the problematic conception that supposes that these tools are linked to the curricular development, as well as to understand that they are a complexity (Gómez-López and Cano, 2011), since they are a social reality of both the students and teachers of today.

However, as Bates (2004: 33) maintains, "if teaching with technology means at least initially more work, the benefits should be considerable", together with the versatility of ICTs, we believe that the benefits of their employment in the university classroom are greater than their disadvantages.

Under this framework European Higher Education Area there is no doubt that Information and Communication Technologies (ICT) will play a very significant role the possibilities they can offer multiple possibilities building international collective knowl- 
edge clusters, provide contextualized and meaningful experiences for students, promote decision making and solving social problems, promote collaborative projects investigation, develop the ability to adapt to new situations, etc. (Cabero, López Meneses, \& Ballesteros, 2009).

As Lorenzo, Trujillo, Lorenzo and Pérez (2011) argue, ICTs are presented as a challenge, but also an opportunity to interact with intelligence, appropriating its complexity and innovating consequently transforming in a meaningful way our society. Perhaps for this reason its knowledge, usefulness and use. Without forgetting the instructional level, also students show marked interests and motivation for using ICT both in their formative processes (Guerra, Gonzalez, \& Garcia, 2010), as well as towards educational resources for mentoring and monitoring didactic processes (García, Gros, \& Noguera, 2010).

\subsection{From the Internet to social networks}

The growth of the Internet has meant that under its umbrella have been generating an infinite number of tools that, initially, are created for Internet as an integral part of the network itself, more so if given the possibilities of today. Its use within the world of higher education has led to the development of a new way of looking at teaching, and as one of its main advantages, is the growth of online training plans, which, as Gavari (2006, p. 190) pointed out, can range from the "promotion of digital literacy; the European virtual campuses; the electronic twinning of European schools and the promotion of teacher training; and the transversal actions for the promotion of e-learning in Europe".

However, using the Internet in the university classroom is not without drawbacks that Barroso already identified in 2004:

- the cost of equipment-means;

- the need to train and maintain a technical staff - and as well, the training of teachers;

- See the students as technicians, and also the adaptation to new teaching-learning methods;

- the excessive belief that there is total security, and the concretion of scientific authorship. 
- the bandwidth;

- the various static environments used for the distribution of information (we refer to files of type pdf or txt);

- the development of a rote approach to learning;

- lack of educational experience does not consider the network as a formative medium.

But this same author also indicates a series of benefits such as:

- training focused on the student;

- communication between the students and the teachers, and in addition the institution;

- the reduction of costs, economic and personal flexibility of the teaching-learning process, as well as the rhythm of the same marked by the students;

- expansion of work scenarios;

- increase in the number of students per teacher and classroom;

- combination of different resources and the possibility of using them in a synchronous and asynchronous way of communicating

Rieh (2004) considers that the combination of factors such as the context, the characteristics of the subjects, and the use of different ICTs provides diverse learning opportunities as a result of the search for information

The Internet or Web 2.0 network, as they have called it since O'Reilly (2005) coined the term 2.0, which has also been transferred to education, since there is already someone who talks about a 2.0 education (Cabero, 2009), a university 2.0 (Freire \& Brunet, 2010) or a student 2.0 (Thomas \& Li, 2008) -, is presented to the educational community as a platform for the exchange of information and ideas, which is in continuous growth, where programs, or a large number of them, with free access trying to overcome new concepts that the Internet or Web 2.0 has brought as it is the digital divide, as well as the management of data that Internet users acquire during their participation .

Holcomb \& Beal (2010) point out that the rapid growth of Web 2.0 implies, at an educational level, that teachers must be critical when choosing the tools, they will use, they must also be very selective and aware of the potential and limitations may present 
itself, both for the development of the curriculum by students, qualified by some as digital natives, by others as part of the Einstein generation (Boschman, 2007; Prensky 2008). The tools have been called 2.0, as well as the network itself, that we usually refer to as Web 2.0.

However, if they are considered as a cardinal tool in their learning process, proof of this is the data collected by Holcomb \& Beal (2010) on the 2.0 tools. In their study, these authors recognize that these are a vehicle for the student to develop a learning based on curiosity and creativity, acquire knowledge through problem-based learning, provide opportunities for their interactive learning, regardless of their geographic location, or their socio-economic status.

Social networks are a new way of being and being present in the world, digital or not.

\subsection{University social network scenario}

The advancement of the Internet in general, and of social networks in particular, has caused higher education to find a space in said communicative universe. Secondary education has developed various actions that allow a resource such as social networks with a large presence in the personal and family life of students to take on an educational aspect.

This situation has reached a great extent in the university training levels, and there are already numerous networks created around various topics aimed at both professors and university students.

A clear example is found in the REDDOLAC network (image 1), Teachers' Network of Latin America and the Caribbean. This, although it covers teachers from all educational levels, offers a great variety of resources and information at the level of higher education.

Users can generate their own pages, in which they can insert information, videos, create a blog or open chat sessions with different themes or participate in existing ones. The incorporations made by the web may arrive easily at the email account with which the user has registered in the network, this being a fluid way of communication. 


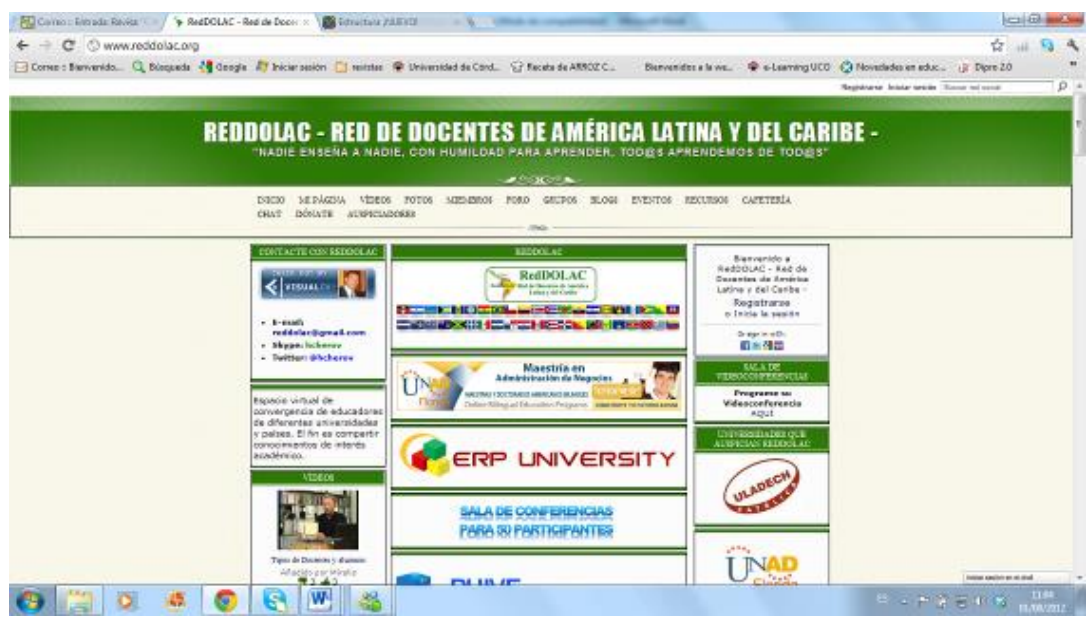

Image 1. REDDOLAC network input. Source: <http://www.reddolac.org/>

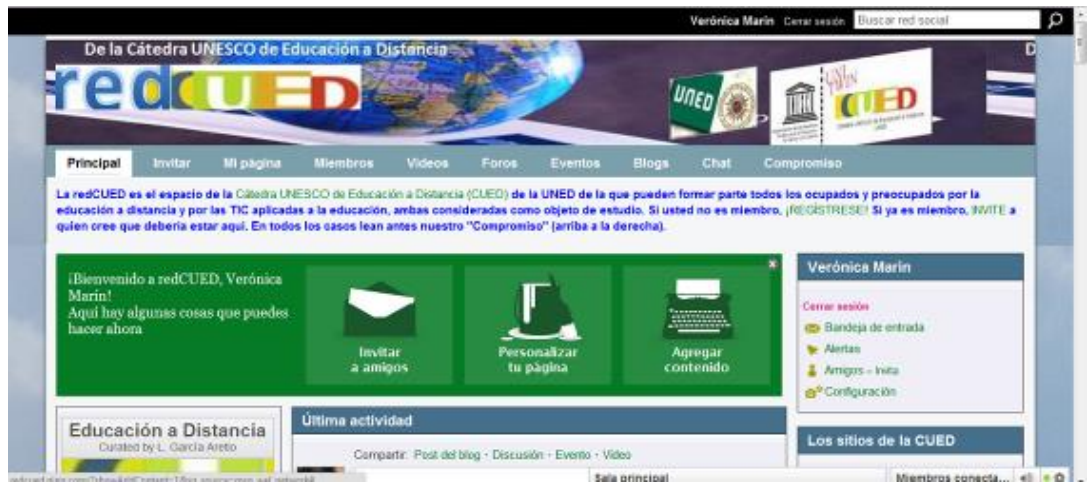

Image 2. Network session RECUED. Source: <http://redcued.ning.com/?showAddContent=1\&xg_source $=$ msg_wel_network $>$

Another example of an educational social network is Redtecnologiaeducativa. This virtual community is supported by the association RUTE, University Network of Educational Technology. Created in the Ning environment centers its attention and content, as indicated by its title, in educational technology. It involves teachers and people interested in the world of information technology and communication. Like the previous network, it allows users to create their own page, participate by uploading photos, videos, creating forums, reporting events and designing blogs around technological topics of interest. 
Among the groups created (7), the so-called university e-learning, consisting of 62 members at the time of the consultation, stands out.

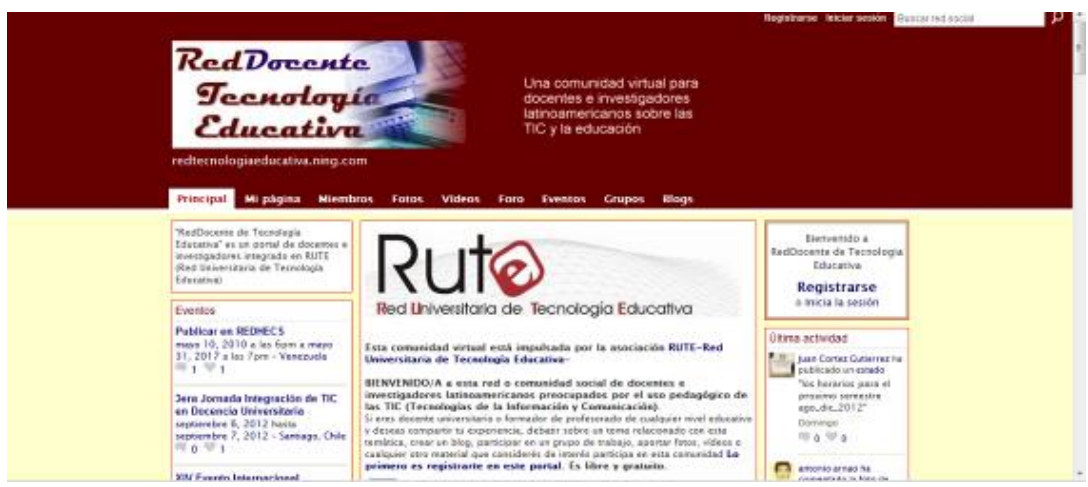

Image 3. Rute Portal. Source: <http://redtecnologiaeducativa.ning.com/>

Like the previous two networks, the Internet in the classroom revolves around technology. You can also engage both teachers and interested 2.0 tools that can be used or can affect education at any educational level. In it we can find a section called Good practices 2.0 designed to expose those practices that are being developed in schools and that are considered as an example to be followed by other teachers.

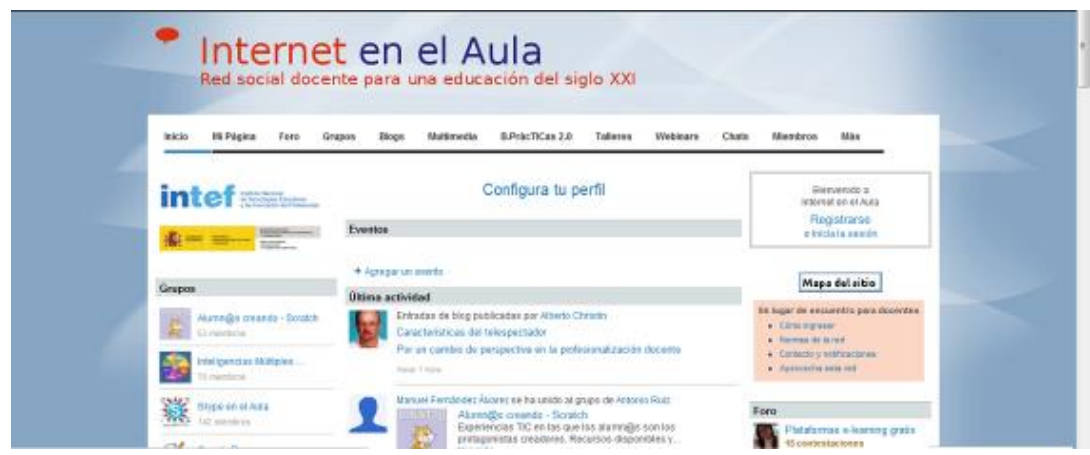

Image 4. Internet portal in the classroom. Source: <http://internetaula.ning.com/>

Focused on university levels, we find the network created by the Menéndez Pelayo International University (UIMPE 2.0) (see image 5). 


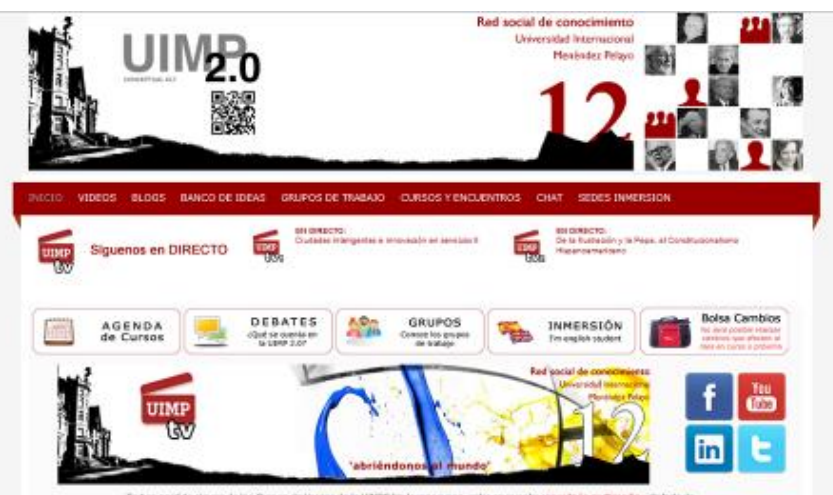

Image 5. Social network of the UIMP. Source: <http://redsocial.uimp20.es/>

In addition, to the aspects indicated in the other networks of a more general scope, it informs us of the courses and meetings that the UIMP develops throughout the academic year, mainly in its summer school, allowing to participate through the chats in a direct way in the conferences that take place in it. With the simple registration as a user, the network will keep the Internet informed about everything that happens in those areas in which the UIMP participates.

\section{UNIVERSITY IN CLOUD}

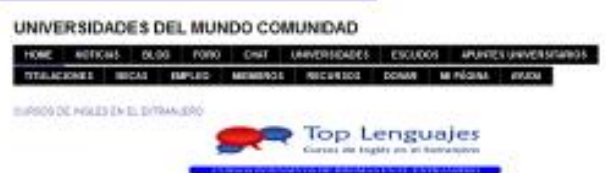

University In Cloud.com All Universities Around The World

Comunidad de Recursos Universitarios

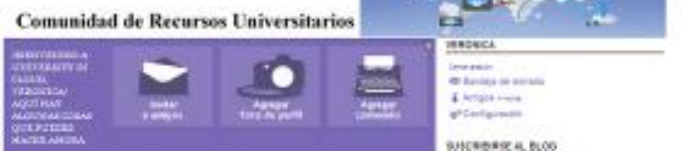

Image 6. Portal University in Cloud.com. Source: <http: //www.universityincloud.com/> 
In the network Universityincloud.com is oriented, fundamentally to university or pre-university students. In it, Internet users can find information from all the universities in the world. Once registered one can locate information about campuses, residences, exams, contact various professors or deans of different universities, open a blog, participate in the forums created or generate a new one, as well as being able to track the university where one can best develop one's learning, from one's needs and/or expectations

Following this line, we also find Gonway. This social network aims to bring the world of business to university students, giving a twist to the proposal that frames the Linkedin network.

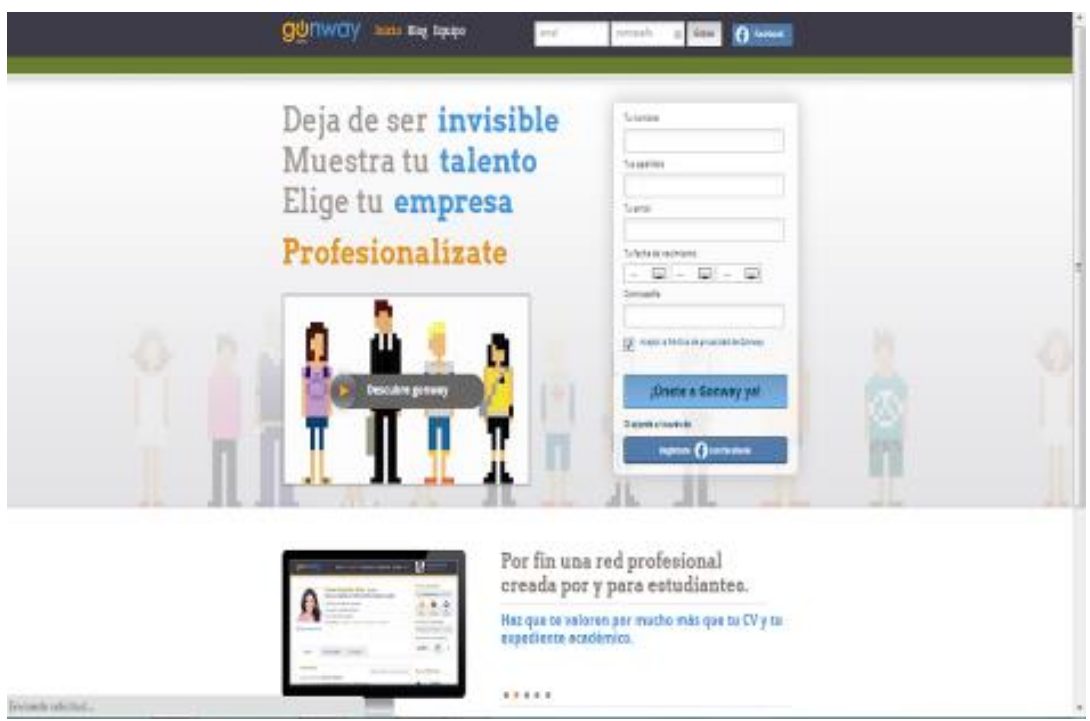

Image 7. Gonway Portal. Source: <https://www.gonway.com/>

Through its slogan "Stop being invisible, show your talent, choose your company" it tries to help seniors and recent graduates seek employment by offering competence to various companies, but knowing in advance the reality of these entities.

We also find in the network the SPQR proposal, a project through the network that aims at raising awareness around the initiative sponsored by the Orange Foundation that is being developed for the inclusion of subjects with hearing loss. Through the use of QR codes you can access information that otherwise, given your situation you cannot access. 


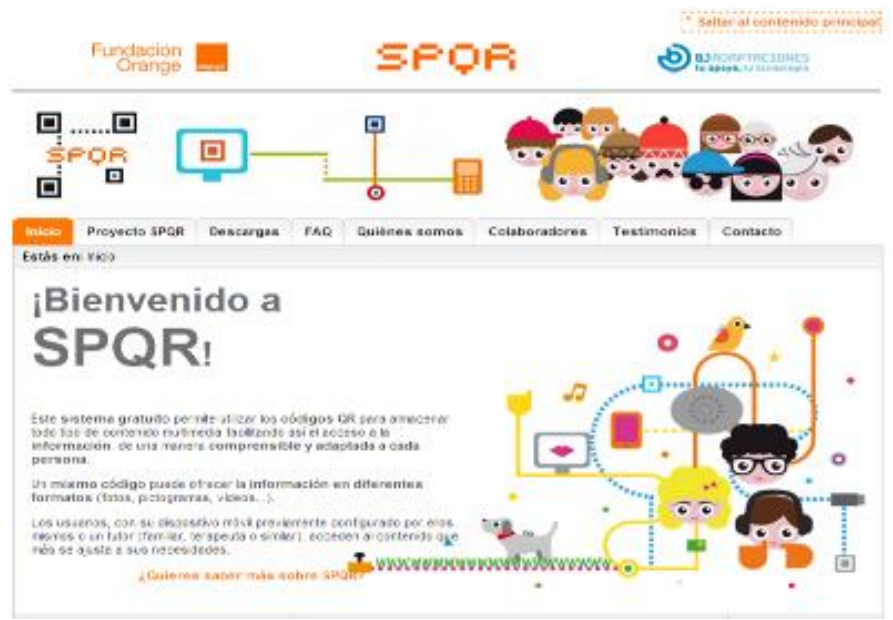

Image 8. SPQR Portal. Source: <http://www.specialqr.org/index.php>

The National University of Colombia, like many others, has created a Facebook profile (see image 9) created through the UN News Agency, of the university itself. Through this page university students are informed of everything that happens on the campus of the National University.

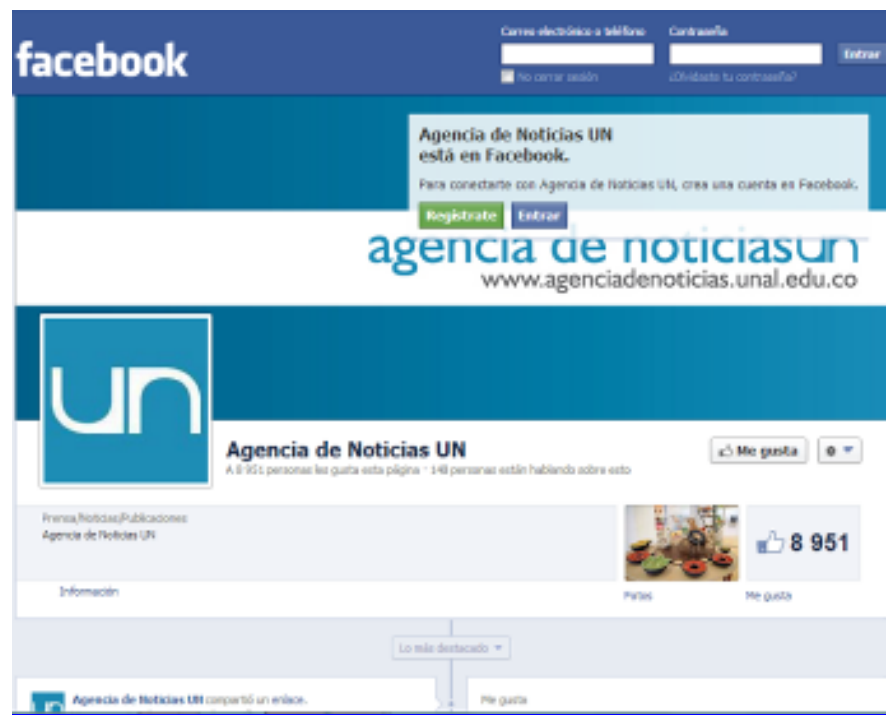

Image 9. UN Facebook page. Source: <https://www.facebook.com/pages/ Agencia-de-Noticias-UN/193658967327822> 
Finally, we want to highlight the DIPRO 2.0 network. This network is the result of the development of an R \& D \& I research project, which focuses on the world of technologies, specifically around personal learning environments (PLE). Composed of more than thirty teachers both university and not, whose common points are information and communication technologies. The substantial difference of this network against the others is, in addition to the specific theme (PLE), that the participant in it can directly select the subjects from which it wishes to receive information, when these incorporate some content into the network, and is able to manage all of this through the make friends option. The greatest difficulty of this network is the ignorance of the Internet users of its software, as opposed to the advantage of being free of charge.

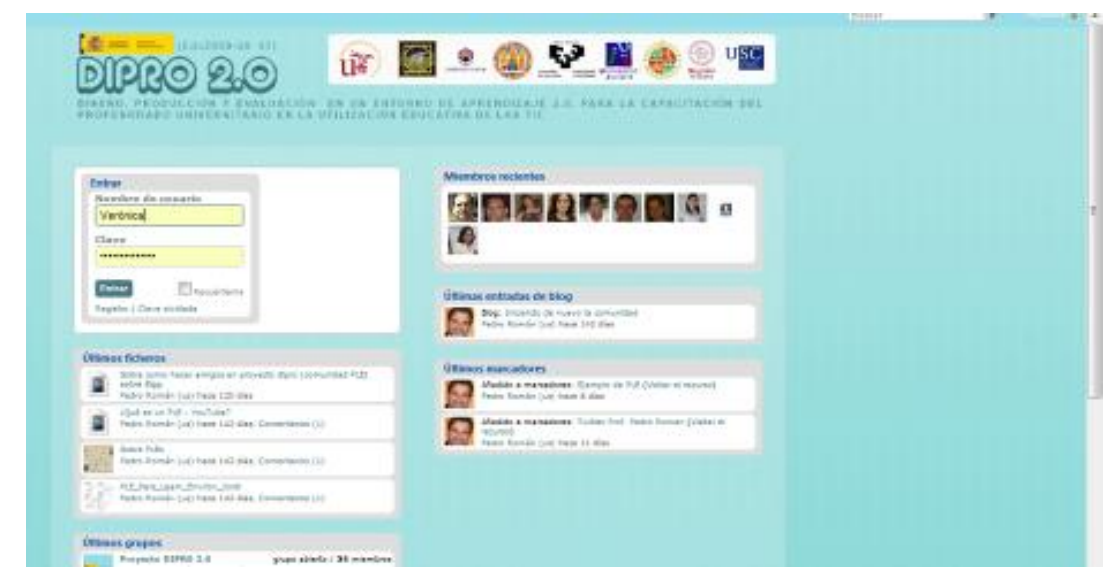

Image 10. Gate DIPRO 2.0. Source: <http://tecnologiaedu2.us.es:8083/>

\subsection{Final reflections}

The development of the information and knowledge society, and in particular of the Internet network, has led to the creation of new tools, called 2.0, which have gradually been incorporated into the educational world.

This situation has revealed not only the gaps that teachers can present to apply them or incorporate them into classroom dynam- 
ics. In addition to this, we can find the use by students of these tools for both social and educational purposes. And this is what this communication wants to emphasize. Tools such as social networks are transcending the conception with which they had been originally created, taking now to the educational field. So, we raised the first question that gives title to this communication: "Are they really necessary social networks for the development of university teaching; "Do they make sense as a resource for the implementation of new study plans?" "Should they be incorporated into the university teaching methodology?" Given the examples we have shown, in addition to all those which have remained in the pipeline, social networks are vital for the development of academic and social life on university campuses, bringing academic life closer to students, to teachers, and to the citizen community. As far as university teaching is concerned, we find the same reality as on the campus, bringing teaching closer to the learning process of the daily reality of the student, forming him or her in all the teaching-learning processes; this is why we can consider that the ICT approach to the network is becoming a cardinal tool in the growth of the study plans resulting from the implementation of the European Higher Education Area.

\section{References}

Álvarez, G. (2012). Las nuevas tecnologías en el contexto universitario: sobre el uso de los blogs para desarrollar las habilidades de lectoescritura de los estudiantes, Revista de Universidad y Sociedad del Conocimiento (RUSC), 9 (2), 3-17. Available at <http://rusc.uoc.edu/ ojs/index.php/rusc/article/view/v9n2-alvarez/v9n2-alvarez>.

Barroso, J. (2004). La red como instrumento de búsqueda de información y de comunicación. In Cabero, J. \& Romero, R. (dirs.), Nuevas tecnologías en la práctica educativa. Sevilla: Arial, pp. 149-184.

Bates, A. (2004). La planificación para el uso de las TIC en la enseñanza. In Sangrá, A. \& González-Sanmamed, M. (coords.), La transformación de las universidades a través de las TIC: discursos y prácticas. Barcelona: Editorial UOC, pp. 31-51.

Bidarian, S. H., Bidarian, S., \& Davoudi, A. M. (2011). A model for application of ITC in the process of teaching and learning, Procedia Social and Behavioral Sciences, 29, 1032-1041. 
Boschman, J. (2008). Generación Einstein. Más listos, más rápidos y más sociables. Barcelona: Gestión 2000.

Cabero, J. (2009). Educación 2.0. ¿Marca, moda o nueva visión de la educación? In Castaño, C. (coord.), Web 2.0. El uso de la web en la sociedad del conocimiento. Investigaciones e implicaciones educativas. Venezuela: Universidad Metropolitana (pp. 9-30).

Cebrián de la Serna, M. (coord.) (2003). Enseñanza virtual para la innovación universitaria. Madrid: Narcea.

Freire, J. \& Brunet, K. S. (2010). Políticas y prácticas para una universidad digital, La Cuestión Universitaria, 6, 85-94.

García, I., Gros, B., \& Noguera, I. (2010). La relación entre las prestaciones tecnológicas y el diseño de las actividades de aprendizaje para la construcción colaborativa del conocimiento, Cultura y Educación, $22(4), 387-394$.

Gavari, E. (2006). Los principios rectores del espacio europeo de educación superior virtual, Revista Electrónica Teoría Educativa, 7 (2) 185-197.

Gómez-López, J., \& Cano, J. (2011). El pensamiento docente y su influencia en la implantación de las tecnologías de la información y la comunicación en el aula: desafíos y oportunidades, Contextos Educativos, 14, 67-83.

Holcom, L. B., \& Beal, C. M. (2010). Capitalizing on web 2.0 in the social studies context, TechTrends, 54 (4), 28-32.

Lorenzo, M., Trujillo, J. M., Lorenzo, R., \& Pérez, E. (2011). Usos del weblog en la Universidad para gestión de conocimiento y trabajo en red, Pixel Bit, Revista de Medios y Educación, 39, 141-154.

Meneses, G. (2006). Universidad: NTIC, interacción y aprendizaje, Edutec, Revista Electrónica de Tecnología Educativa, 20, 1-11. Available at <http://edutec.rediris.es/Revelec2/revelec20/meneses20.htm>.

Muñoz, L. A. (2004). Las tecnologías de la información y la comunicación y la formación en entornos virtuales, Revista Complutense de Educación, 15 (1), 51-74.

O'Reilly, T. (2005). What is Web 2.0. Design patterns and business models for the next generation of software. Available at <http://oreilly.com/web2/ archive/what-is-web-20.html>.

Prensky, M. (2008). Turning on the lights, Educational leadership Magazine, 65 (6), 40-45. Available at <http://www.ascd.org/publications/educational-leadership/mar08/vol65/num06/Turning-On-the-Lights.aspx>.

Rieh, S. (2004). On the web at home: information seeking and web searching in the home environment, Journal of the American Society Information Science and Technology, 55 (8), 743-754. 
Thomas, D. A. \& Li, Q. (2008). From Web 2.0 to teachers 2.0. Computers in the Schools, 25 (3/4), 199-210.

Uzunboylu, H., Bicen, H., \& Cavus, N. (2011). The efficient virtual learning environment: a case study of web 2.0 tools and windows live spaces, Computers \& Education, 56, 720-726. 
